\title{
Accumulation of Calcium and Phosphate Stimulated by Carboxylic Antibiotics into Mitochondria*
}

\author{
Sergio Estrada-O., Carlos de Céspedes $†$ and Esthela Calderón \\ Departamento de Bioquimica \\ Centro de Investigación y de Estudios Avanzados del \\ Instituto Politécnico Nacional A Đdo. Postal 14-740, México 14 D.F., México
}

Received 14 December 1971

\section{Abstract}

Carboxylic ionophores such as nigericin, dianemycin, the monensins and compounds Lilly A $2: 7$ or X-537 A, stimulate an electron-transport dependent accumulation of $\mathrm{Ca}^{2+}$ and phosphate into mitochondria. Ion accumulation is stimulated under conditions of limited $\mathrm{Ca}^{2+}$ loading imposed by phosphate in the presence of $\beta$-hydroxybutyrate. Carboxylic ionophores do not affect divalent ion uptake when $\beta$-hydroxybutyrate is replaced for by succinate. They block $\mathrm{Ca}^{2+}$ and phosphate accumulation when energy is provided from the hydrolysis of ATP, or from the oxidation of glutamate, $\alpha$-ketoglutarate, pyruvate or glutamate + malate. Nigericin-like antibiotics also transform the indefinite prolongation of state 3 respiration induced by $\mathrm{Ca}^{2+}$ and phosphate on $\beta$-hydroxybutyrate oxidation, into tightly coupled state 3 to 4 transitions. Evidence suggests that electrophoretic $\mathrm{Ca}^{2+}$ transport occurs in parallel with proton or $\mathrm{K}^{+}$ carriers. The anion movements associated to $\mathrm{Ca}^{2+}$ uptake are most probably driven by the existent $\Delta \mathrm{pH}$ across the mitochondrial membrane.

It is known that the translocation of $\mathrm{Ca}^{2+}$ energized by substrate oxidation or by AIP hydrolysis, is linked to the efflux of protons in intact mitochondrial membranes $[\mid-6]$.

It has also been reported that an oligomycin-insensitive efflux of $\mathrm{K}^{+}$ induced by valinomycin in non-respiring mitochondria stimulates the translocation of $\mathrm{Ca}^{2+}$ into these organelles [7-9].

* This study was supported by grants from the Research Corporation and The Fund for Overseas Research Grants and Education.

† Present Address: Department of Biological Chemistry. The University of Michigan, Ann Arbor, Michigan.

Copyright (c) 1972. Plenum Publishing Company Limited. No part of this publication may be reproduced, stored in a retrieval system, or transmitted, in any form or by any means, electronic, mechanical, photocopying, microfilming, recording or otherwise, without written permission of Plenum Publishing Company Limited. 
The evidence hereby presented indicate that several carboxylic antibiotics from the nigericin family stimulate an electron transportdependent accumulation of $\mathrm{Ca}^{2+}$ and phosphate into mitochondria. It is suggested that the membrane potential changes gencrated upon the induced efflux of protons and $\mathrm{K}^{+}$from mitochondria, parallel to the simultaneous translocation of some oxidizable substrates and phosphate, facilitate the electrophoreic flux of $\mathrm{Ca}^{2+}$ into mitochondria. The possibility that nigericin-like compounds operate as mobile carriers for $\mathrm{Ca}^{2+}$ transport is also considered.

\section{Materials and Methods}

Mitochondria were prepared from livers of male rats weighing $125.150 \mathrm{~g}$ as described by Johnson and lardy [10]. The initial homogenization step was carried out in the presence of 1 mM EDTA.

\section{Measurement of $\mathrm{K}^{+}$and $\mathrm{H}^{+}$Movements and Oxygen Uptake}

A continuous recording of oxygen consumption and variations in the extramitochondrial concentration of $\mathrm{K}^{+}$and $\mathrm{H}^{+}$was carried out using an apparatus designed, developed and constructed by Chance, Mayer, Pressman and Graham [11-13].

Measurement of the Accumulation of $\mathrm{Ca}^{2+}$ and Inorganic Phosphate in Liver Mitochondria

Rat liver mitochondria were incubated and rapidly isolated as previously described [14-16]. The accumulated orthophosphate was extracted by the procedure of Falcone and Witonsky [17] and measured in the organic solvent phase by determination of the radiosactivity when ( $\left.{ }^{32} \mathrm{P}\right) \mathrm{Pi}$ was used, or chemically by the method of Martin and Doty [18] as modified by Lindberg anll Ernster $[19]$. The accumulated $\left({ }^{45} \mathrm{Ca}\right) \mathrm{Ca}^{2+}$ was measured in the aqueous phase of mitochondrial extracts obtained after rapid centrifugation of the incubation vessel contents.

\section{Other Analytical Procedures}

Radioactivity measurements were made with a Nuclear Chicago gas-flow low background counter. ATPase activity was measured as described by Lardy and Wellman [20]. Inorganic phosphate from ATP hydrolysis was determined as described [21]. Mitochondrial protein was estimated by the Biuret method. $\left({ }^{32} \mathrm{P}\right) \mathrm{Pi}$ was obtained from Tracerlab (Waltham, Mass.); $\left({ }^{45} \mathrm{Ca}\right)-\mathrm{Ca}^{2+}$ was obtaincd from Amersham Searle Co. The antibiotics nigericin, dianemycin, monensin $\mathrm{A}, \mathrm{X}-537 \mathrm{~A}$, lilly $\mathrm{A}-217$ 
and nonactin used in these expcriments were a generous gift from Dr. Henry A. Lardy, The Institute for Enzyme Research, University of Wisconsin, and Dr. Marvin Gorman, The Lilly Research Laboratories.

\section{Results}

In the presence of $\beta$-hydroxybutyratc and inorganic phosphate, increasing concentrations of nigericin stimulate the aerobic accumulation of $\mathrm{Ca}^{2+}$ into mitochondria (Fig. 1). Such phenomenon is prevented when either $\beta$-hydroxybutyrate or phosphate are omitted (Fig. 2) or else when $5 \times 10^{-7} \mathrm{M}$ antimycin or $2 \times 10^{-7} \mathrm{M}$ rotenone are added to the medium. It is apparent that very low concentrations of nigericin $\left(1 \times 10^{-7} \mathrm{M}\right)$, are required for the antibiotic to stimulate maximal accumulation of $\mathrm{Ca}^{2+}$ into mitochondria.

Figure 2 (panel A) shows a plot of the magnitude of $\mathrm{Ca}^{2+}$ uptake induced by $3 \times 10^{-7} \mathrm{M}$ nigericin versus concentrations of $\mathrm{Ca}^{2+}$ added.

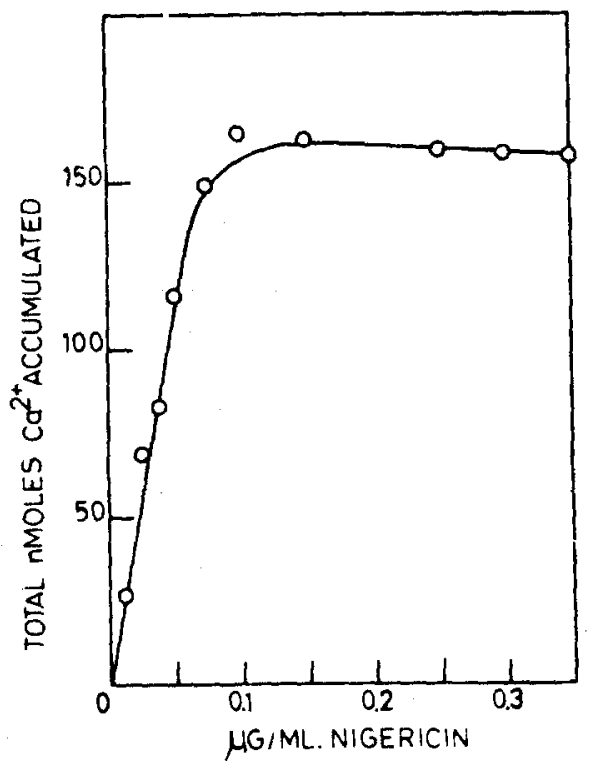

Figure 1. The effect of the concentration of nigericin on the accumulation of $\mathrm{Ca}^{2+}$ in liver mitochondria in the presence of $\beta$-hydroxybutyrate and phosphate. The reaction mixture contained: $10 \mathrm{nM}$ triethanolamine $\left(\mathrm{Cl}^{-}\right) \mathrm{pH} 7.4,15 \mathrm{mM} \mathrm{KCl}$, $2.5 \mathrm{mM}$ phosphate (TEA) $200 \mu \mathrm{M} \mathrm{CaCl}_{2}, 20,000$ c.p.m. $\left({ }^{45} \mathrm{Ca}\right)-\mathrm{Ca}^{2+}, 10 \mathrm{mM}$ $\beta$-hydroxybutyrate, $200 \mathrm{mM}$ sucrose, the indicated concentrations of nigericin and approximately $9 \mathrm{mg}$ protein $\mathrm{N}$ of mitochondria in $2.0 \mathrm{ml}$ volume at $28^{\circ}$. After $10 \mathrm{~min}$ incubation, the mitochondria were rapidly isolated and the radioactivity of $\left({ }^{45} \mathrm{Ca}\right)-\mathrm{Ca}^{2+}$ determined in the pellets. 


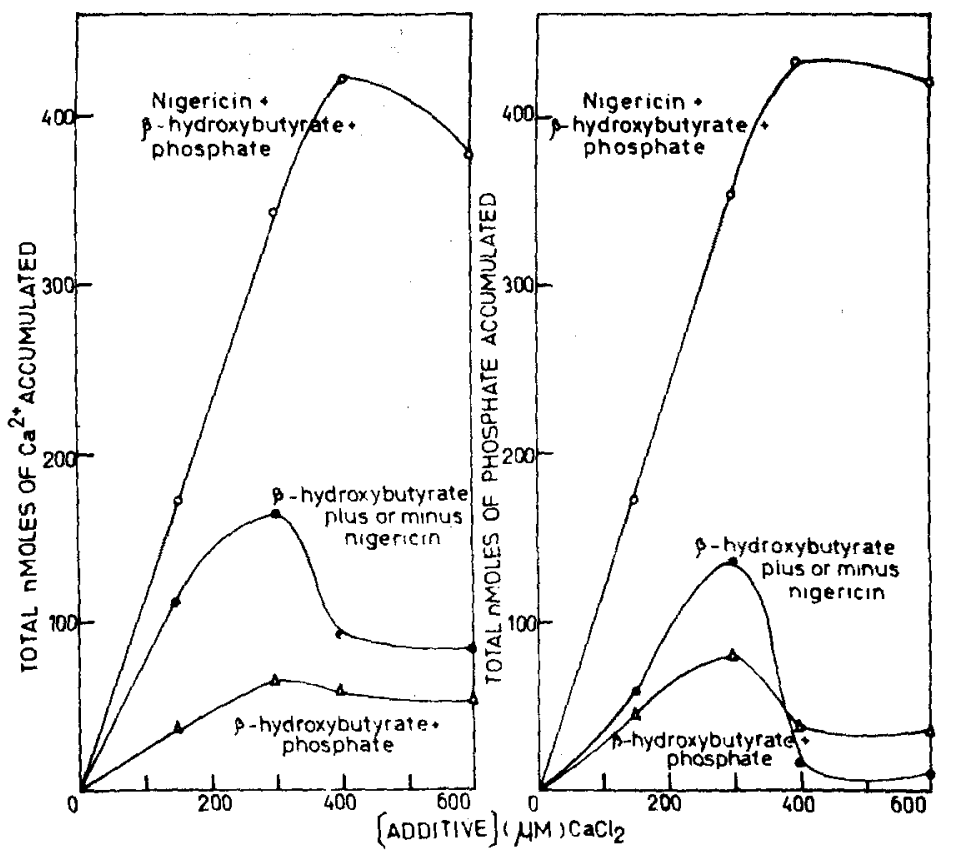

Figure 2. The effect of calcium concentration on the accumulation of $\mathrm{Ca}^{2+}$ and inorganic phosphate stimulated by nigericin in liver mitochondria. The experimental conditions were essentially those of Fig. I except for the indicated concentrations of $\mathrm{Ca}^{2+}$ and that of $0.1 \mu \mathrm{g} / \mathrm{ml}$ nigericin. Panel $A$ shows a plot of the accumulation of $\left({ }^{45} \mathrm{Ca}\right)-\mathrm{Ca}^{2+}$ against $\mathrm{Ca}^{2+}$ concentration in the medium. Panel $B$ indicates the dependence of the accumulation of inorganic phosphate on $\mathrm{Ca}^{2+}$ concentration.

The antibiotic not only prevents the inhibitory effect of orthophosphate on $\mathrm{Ca}^{2+}$ retention [22] but also clearly stimulates $\mathrm{Ca}^{2+}$ accumulation above the levels energized by $\beta$-hydroxybutyrate alone or with added phosphate. Panel B of Fig. 2 indicates that nigericin also stimulates the net accumulation of orthophosphate from the medium, when mitochondria are supplemented with $\beta$-hydroxybutyrate and increasing concentrations of $\mathrm{Ca}^{2+}$. Maximal $\mathrm{Ca}^{2+}$ or phosphate accumulation is induced by nigericin at an external concentration of $400 \mu .1 / \mathrm{Ca}^{2+}$; higher concentrations of $\mathrm{Cat}^{2+}$ tend 60 inhibil net $\mathrm{Ca}^{2+}$ and phosphatc uptake in a parallel form.

Nigericin does not affect $\mathrm{Ca}^{2+}$ or phosphate translesation in the absence of added inorganic phosphate regardless of the presence of oxidizable substrates or ATP. Appirently, phosphate must inhibit $\mathrm{Ca}^{2+}$ loading [22] for the antibiotic to stimulate net $\mathrm{Ca}^{2+}$ uptake into mitochondria. The translucation of $\mathrm{Ca}^{2+}$ stimulated by nigericin is negligible when $\beta$-hydroxybutyrate is replaced for by succinate in the 
presence of orthophosphate. Moreover, the carboxylic ionophore almost completely blocks the accumulation of $\mathrm{Ca}^{2+}$ and phosphate linked to glutamate, $\alpha$-ketoglutarate or malate oxidation. Thus, except where indicated, most of the experiments to be described were carried out with $\beta$-hydroxybutyrate as encrgy source for ion transport.

As shown in Fig. 3, the accumulation of $\mathrm{Ca}^{2+}$ stimulated by nigericin is sensitive to the concentration of protons in the medium. An increase of $\mathrm{Ca}^{2+}$ uptake is induced by the carboxylic antibiotic from $\mathrm{pH} 6.0$ to 6.5, whereas a progressive decrease is observed above $\mathrm{pH} 7.0$. Identical $\mathrm{pH}$ values are found for the accumulation of phosphate stimulated by nigericin. The antibiotic does not stimulate $\mathrm{Ca}^{2+}$ or phosphate uptake into mitochondria above pH 8.0.

The ability of carboxylic ionophores to stimulate $\mathrm{Ca}^{2+}$ uptake is also sensitive to the concentration of mitochondrial protein nitrogen in the medium. It is apparent that the protein/antibiotic ratio is implicated with the extent of divalent ion accumulation (Table I). Parallel results to

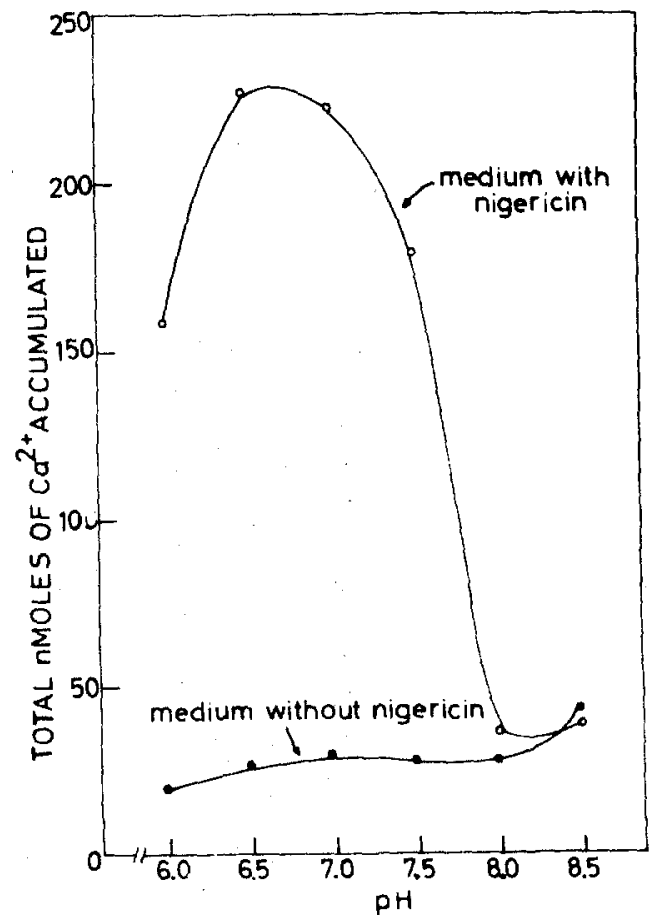

Figure 3. The effect of $\mathrm{pH}$ change on the accumulation of $\mathrm{Ca}^{2+}$ which occurs in the presence of nigericin, $\beta$ hydroxybutyrate and phosphate in liver mitochondria. The reaction mixture for these experiments was similar to that of Fig. 1 except for the addition of $6 \mathrm{mM}$ histidine and variable concentrations of $\mathrm{HCl}$ to obtain the indicated $\mathrm{pH}$ values. The concentration of nigericin used was $0.1 \mu \mathrm{g} / \mathrm{ml}$. 
TABLE I. The effect of the concentration of mitochondria protein $\mathrm{N}$ on the extent of calcium accumulation mediated by nigericin

\begin{tabular}{ccc}
\hline $\begin{array}{c}\text { Total concentration of mitochondrial } \\
\text { protein nitrogen }\end{array}$ & $\begin{array}{c}\mathrm{Ca}^{2+} \text { accumulated } \\
\text { without nigericin }\end{array}$ & $\begin{array}{c}\mathrm{Ca}^{2+} \text { accumulated in the } \\
\text { presence of nigericin }\end{array}$ \\
& Total nmoles of $\mathrm{Ca}^{2+}$ accumulated \\
1.65 & 15 & 23 \\
3.3 & 23 & 44 \\
4.95 & 33 & 43 \\
6.6 & 37 & 98 \\
9.9 & 55 & 143 \\
13.2 & 79 & 188 \\
19.8 & 160 & 188 \\
23.1 & 165 & 185 \\
\hline
\end{tabular}

The reaction mixture contained $10 \mathrm{nM}$ triethanolamine $(\mathrm{Cl}) \mathrm{pH} 7.4,15 \mathrm{mM} \mathrm{KCl}$, $2.5 \mathrm{mM}$ phosphate (TEA), $150 \mu \mathrm{M} \mathrm{CaCl}_{2}, 20,000 \mathrm{cpm}\left({ }^{45} \mathrm{Ca}\right)-\mathrm{Ca}^{2+}, 10 \mathrm{mM}$ $\beta$-hydroxybutyrate, $200 \mathrm{mM}$ sucrose, $0.25 \mu \mathrm{g} / \mathrm{ml}$ nigericin and the indicated concentrations of mitochondrial protein added in $2.0 \mathrm{ml}$ volume at $25^{\circ}$. A zero time value $\left(\mathrm{Ca}^{2+}\right.$ accumulated in mitochondria incubated with $1 \mathrm{mg} / \mathrm{ml}$ antimicin and rotenone plus $5 \times 10^{-5} \mathrm{M}, 2.4$ dinitrophenol), was subtracted from each experimental at the different alternatives reported. Time of incubation $10 \mathrm{~min}$. The isolation of mitochondria after the incubation, as well as the measurement of the radioactivity of $\left({ }^{45} \mathrm{Ca}\right)-\mathrm{Ca}^{2+}$ in the mitochondrial pellets was carried out as indicated in methods.

those obtained for $\mathrm{Ca}^{2+}$ transport have also been found for inorganic phosphate movements in the above parameter.

Different carboxylic antibiotics replace for nigericin to stimulate $\mathrm{Ca}^{2+}$ and phosphate translocation linked to $\beta$-hydroxybutyrate oxidation in mitochondria. This is shown in Table.II. It indicates that nigericin, dianemycin, compound Lilly A-217 (almost identical to HLR-206) monensin A and X-537 A substitute for nigericin in the above effect.

Previous observations by Lardy, Johnson and McMurray [23] showed that low concentrations of nigericin block the ATPase stimulated by $\mathrm{Ca}^{2+}$ in liver mitochondria. As illustrated in Fig. 5, the inhibition by both monensin A or X-537 A of the hydrolysis of ATP stimulated by $\mathrm{Ca}^{2+}$ (Panel A of Fig. 4) is associated to a parallel inhibition by the antibiotics of the accumulation of $\mathrm{Ca}^{2+}$ energized by ATP (Panel B of Fig. 4). Thus carboxylic antibiotics stimulate the accumulation of $\mathrm{Ca}^{2+}$ when mitochondria are energized with $\beta$-hydroxybutyrate in the presence of phosphate, while inhibiting that promoted by ATP.

Table III indicates that electron transport inhibitors as well as proton or cation conductors block the uptake of $\mathrm{Ca}^{2+}$ and phosphate stimulated by nigericin into mitochondria. Antimycin and rotenone as well as 2,4-dinitrophenol or FCCP inhibit such phenomena. Moreover, in the presence of increasing concentrations of $\mathrm{KCl}$, nonactin completely 

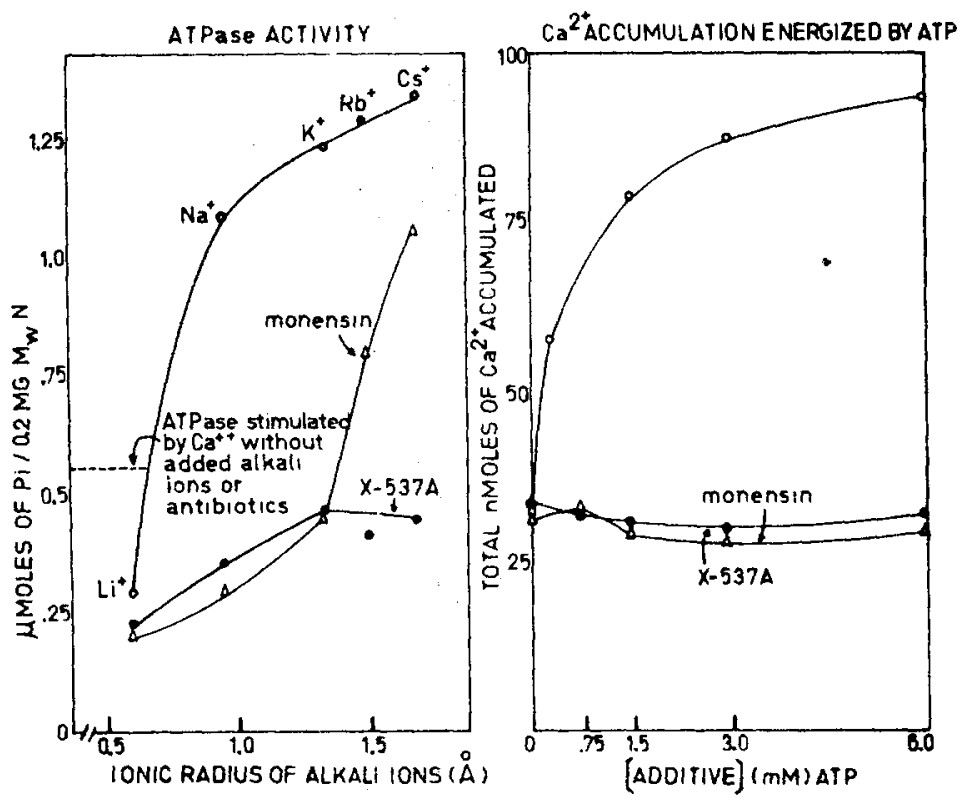

Figure 4. The effect of monensin $A$ and X-537 A on the ATPase activity stimulated by $\mathrm{Ca}^{2+}$ (Panel $A$ ) and the uptake of $\mathrm{Ca}^{2+}$ energized by ATP into mitochondria (Panel $B$ ). The reaction mixture from Panel $A$ contained: $6 \mathrm{mM}$ ATP (Tris) $\mathrm{pH} 7.4,50 \mathrm{mM}$ of the chleride salts of either $\mathrm{Li}^{+}, \mathrm{Na}^{+}, \mathrm{K}^{+}, \mathrm{Rb}^{+}$or $\mathrm{Cs}^{+}$, $400 \mu \mathrm{M} \mathrm{CaCl}, 180 \mathrm{mM}$ sucrose, $1 \mu \mathrm{g} / \mathrm{ml}$ of either HLR.537 or monensin $A$ and $2.6 \mathrm{mg}$ of mitochondrial protein in $1.0 \mathrm{ml}$ volume at $30^{\circ}$. The time of incubation was $10 \mathrm{~min}$. The reaction mixture from Panel $B$ was that of Fig. 1 except for the indicated concentrations of ATP instead of $\beta$-hydroxybutyrate as well as the addition of $400 \mu \mathrm{M} \mathrm{Ca}^{2+}$ and $4.6 \mathrm{mg}$ mitochondrial protein $/ \mathrm{ml}$.

TABLE II. Effect of different carboxylic antibiotics on the accumulation of $\mathrm{Ca}^{2+}$ and phospháte into mitochondria

\begin{tabular}{lcc}
\hline Additions & $\begin{array}{c}\text { Total nmoles of } \mathrm{Ca}^{2+} \\
\text { accumulated }\end{array}$ & $\begin{array}{c}\text { Total nmoles of } \mathrm{Pi} \\
\text { accumulated }\end{array}$ \\
\hline None & 50.93 & 69.00 \\
Nigericin & 221.90 & 275.00 \\
Monensin & 192.80 & 280.00 \\
Dianemycin & 217.00 & 275.00 \\
X-537 & 219.00 & 279.00 \\
Lilly A-217 & 188.00 & 280.00 \\
\hline
\end{tabular}

The reaction mixture was essentially that from Table I, except for the addition of $0.6 \mu \mathrm{g} / \mathrm{ml}$ of the indicated carboxylic antibiotics, $200 \mu \mathrm{M} \mathrm{CaCl}$ and $\mathrm{mg}$ of mitoch ondrial protein nitrogen. 
blocks the uptake of $\mathrm{Ca}^{2+}$ and phosphate stimulated by nigericin (Fig. 5A B). Valinomycin and macrocyclic polyether XXXIV [25] replace for nonactin in such inhibitory action (Table III). From the above data it may be concluded that an energized state of the mitochondrial membrane is necessary for nigericin-like antibiotics to stimulate $\mathrm{Ca}^{2+}$ and phosphate accumulation into mitochondria.

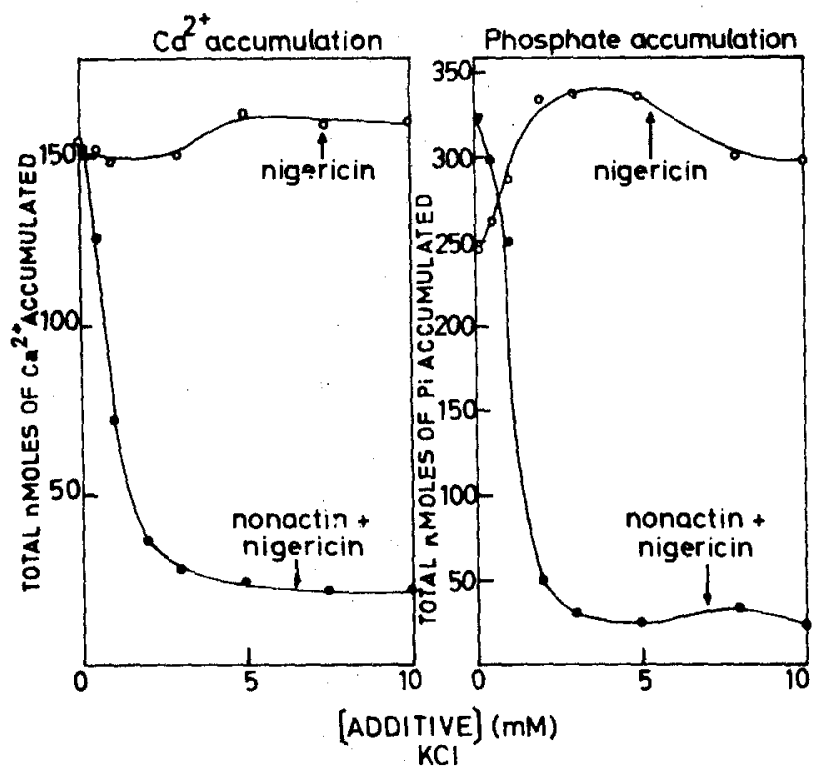

Figure 5. The effect of the concentration of $\mathrm{KCl}$ on the inhibition by nonactin of the accumulation of $\mathrm{Ca}^{2+}$ (Pancl A) or phosphate (Panel B) stimulated by nigericin into mitochondria. The reaction mixture for these experiments was similar to that of Fig. 1, except for the addition of $2 \times 10^{-7} \mathrm{M}$ nonactin, and the indicated concentrations of $\mathrm{KCl}$.

Rossi, Carafoli, Drahota and I,chninger [22] have shown that orthophosphate causes an indefinite prolongation of the state 3 respiration in the presence of $\mathrm{Ca}^{2+}$ and $\beta$-hydroxybutyrate. When the medium is supplemented with nigericin, $\mathrm{Ca}^{2+}$ is capable of inducing state 3 to 4 respiration transitions, even in the presence of $10 \mathrm{mM}$ phosphate (Fig. 6A B). The addition of ADP after $\mathrm{Ca}^{2+}$ and phosphate, causes tightly coupled bursts of oxygen uptake only in the presence of nigericin. Thus, parallel to their ability to stimulate $\mathrm{Ca}^{2+}$ and phosphate uptake in the presence of $\beta$-hydroxybutyrate, carboxylic ionophores prevent the uncoupling effect of phosphate plus $\mathrm{Ca}^{2+}$ on $\beta$-hydroxybutyrate oxidation.

The possible relationship existent between $\mathrm{K}^{+}$and $\mathrm{H}^{+}$movements and the antibiotic induced-Ca ${ }^{2+}$ accumulation in mitochondria is shown in 
TABLE III. The effect of inhibitors of electron transfer and energy conservation as well as cation or proton conductors on the accumulation of $\mathrm{Ca}^{2+}$ stimulated by nigericin into mitochondria

Nigericin plus

(Control) Without nigericin added

Nigericin with no addition

2,4-dinitrophenol

Antimycin

Rutamycin

Rotenone

Valinomycin

Macrocyclic polyether XXXIV
Total nmoles of $\mathrm{Ca}^{2+}$ accumulated into mitochondria

The reaction mixture was idertical to that from Fig. 1 . The concentration of nigericin was $0.25 \mu \mathrm{g} / \mathrm{ml}$. Other additions were as follows: 2,4-dinitrophenol $5 \times 10^{-6} \mathrm{M}$; Antimycin $3 \times 10^{-7} \mathrm{M}$; Rutamycin $1 \times 10^{-6} \mathrm{M}$; rotenone $5 \times 10^{-7} \mathrm{M}$; Valinomycin $1 \times 10^{-6} \mathrm{M}$; Macrocyclic polyether XXXIV $5 \times 10^{-5} \mathrm{M}$.

48.2

225.4

32.2

31.1

216.8

67.4

28.6

38.2

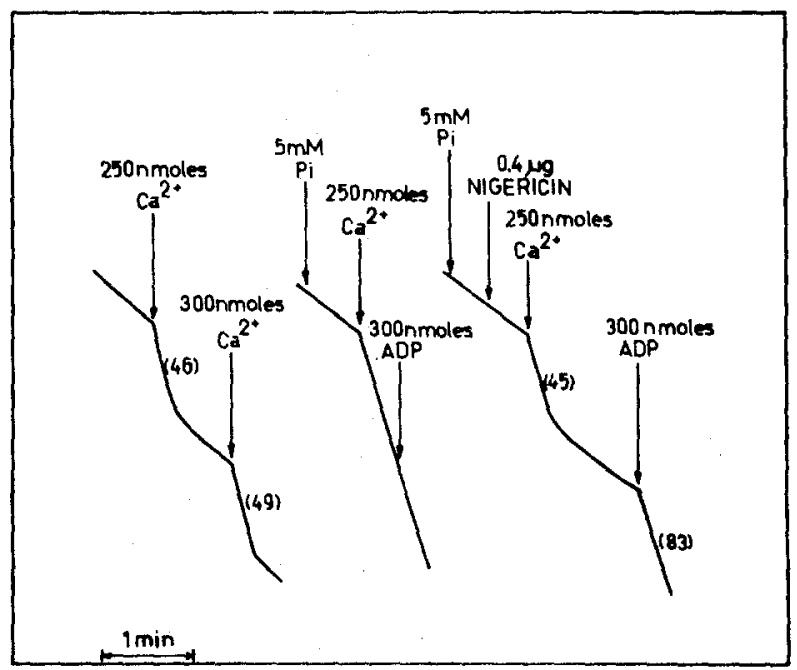

Figure 6. The effect of nigericin and $\mathrm{Ca}^{2+}$ on the respiration of mitochondria oxidizing $\beta$-hydroxybutyrate in the presence of phosphate. 'The reaction mixture contained: $10 \mathrm{mM}$ triethanolamine $\left(\mathrm{Cl}^{-}\right)$pll $7.2,30 \mathrm{mM} \mathrm{KCl}, 3 \mathrm{mM}$ phosphate (TEA), $5 \mathrm{mM} \beta$-hydroxybutyrate ("'EA), $180 \mathrm{mM}$ sucrose, $1.7 \mathrm{mg}$ mitochondrial $\mathrm{N}$, and where indicated, $0.1 \mu \mathrm{gl} \mathrm{ml}$ nigericin, $100 \mu \mathrm{M} \mathrm{CaCl}_{2}$ and $80 \mu \mathrm{M} \mathrm{AIP}\left(\mathrm{Na}^{+}\right)$.

Figs. 7 and 8. Figure 7 shows independent experiments on the effect of the order of addition of $\mathrm{Ca}^{2+}$ and nigericin on $\mathrm{K}^{+}$and $\mathrm{H}^{+}$movements as well as mitochondrial oxygen uptake. Such media was supplemented with phosphate and two different oxidizable substrates. In the presence 

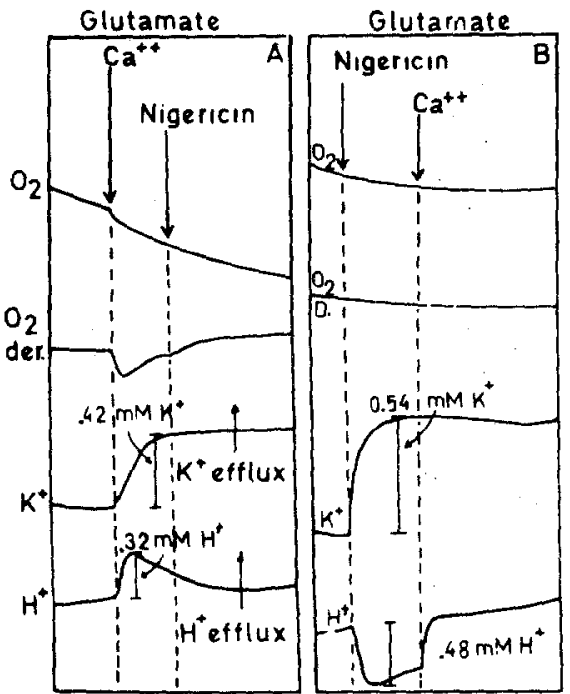

B-hydroxybutyrate $\beta$-hydroxybutyrate
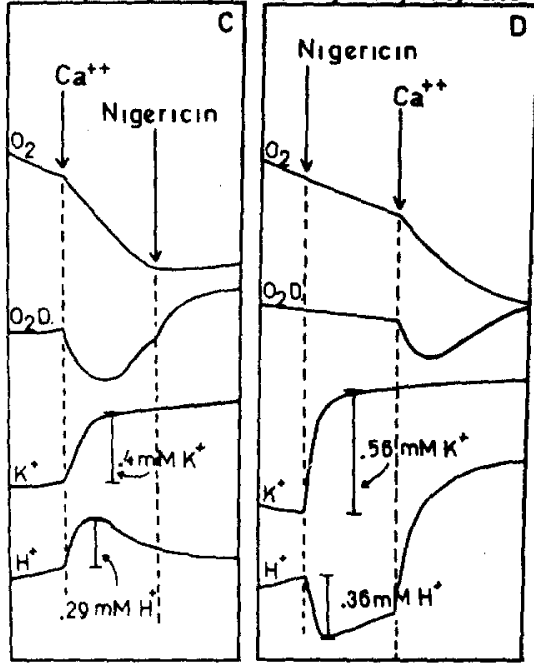

Figure 7. The effect of the order of addition of $\mathrm{Ca}^{2+}$ and nigericin on $\mathrm{K}^{+}$and $\mathrm{H}^{+}$ movements in mitochondria oxidizing glutamate or $\beta$-hydroxybutyrate. An upward deflection of $\mathrm{K}^{+}$or $\mathrm{H}^{+}$tracings represent an increase in the concentration of these ions in the medium or efflux from the mitochondria. The reaction mixture contained: $2 \mathrm{mM}$ triethanolamine $\left(\mathrm{Cl}^{-}\right)$pH 7.4, $3 \mathrm{mM}$ either glutamate or $\beta$ hydroxybutyrate (TEA), $2 \mathrm{mM}$ phosphate (TEA), $4 \mathrm{mM} \mathrm{KCl}, 180 \mathrm{mM}$ sucrose, and $1.4 \mathrm{mg}$ mitochondrial $\mathrm{N}$, in $5 \mathrm{ml}$ volume at $28^{\circ}$. Where indicated, $\mathrm{Ca}^{2+}$ and nigericin were added at a concentration of $200 \mu \mathrm{M}$ and $0.4 \mu \mathrm{g} / \mathrm{ml}$ respectively.

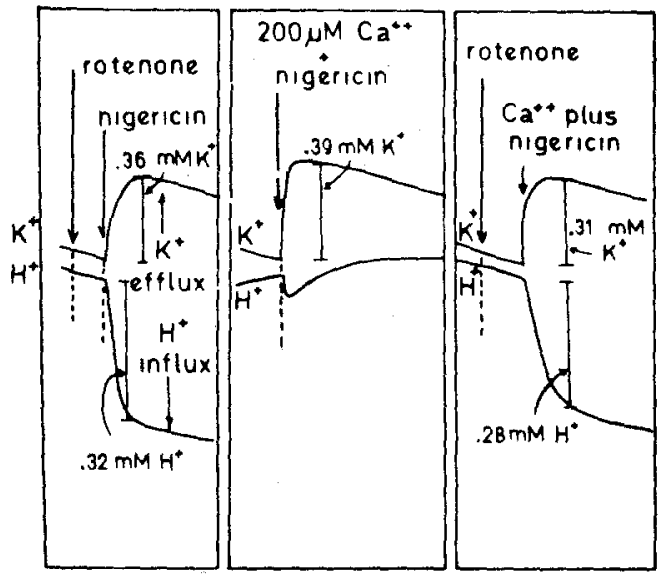

Figure 8. The effect of the simultaneous addition of $\mathrm{Ca}^{2+}$ and nigericin on the movements of $\mathrm{K}^{+}$and protons in aerobically incubated or respiratory-inhibited mitochondria. Experimental conditions were similar to those of Fig. 7 except for the addition of $1 \mu \mathrm{g} / \mathrm{ml}$ of rotenone where indicated. 
of glutamate, $200 \mu \mathrm{M} \mathrm{Ca}^{2+}$ cause a short burst of oxygen uptake, a cyclic efflux of protons and a slow release of mitochondrial $\mathrm{K}^{+}$(Panel A, Fig. 7). The subsequent addition of nigericin does not affect the $\mathrm{K}^{+}$or $\mathrm{H}^{+}$tracings. Essentially similar results in $\mathrm{K}^{+}$and $\mathrm{H}^{+}$movements, except for a faster oxygen uptake rate, are found when $\mathrm{Ca}^{2+}$ is added prior to nigericin in the presence of $\beta$-hydroxybutyrate (Panel $\mathrm{C}$ of Fig. 7). The oxidation of this latter substrate is not inhibited by carboxylic ionophores $[13,23]$. When nigericin is added prior to $\mathrm{Ca}^{2+}$ in the presence of glutamate (Panel B of Fig. 7), it causes a rapid release of $\mathrm{K}^{+}$ in exchange for external protons. It also inhibits glutamate oxidation. The subsequent addition of $\mathrm{Ca}^{2+}$ only results in a reversal to the base line of the nigericin-mediated $\mathrm{H}^{+}$influx, without affecting the $\mathrm{K}^{+}$tracing. On the other hand, when this experiment is carried out in the presence of $\beta$-hydroxybutyrate (Panel D of Fig. 7), the addition of $\mathrm{Ca}^{2+}$ after nigericin causes a large and very slowly reversible proton efflux subsequent to the antibiotic-induced $\mathrm{K}^{+}$release. It is only with this latter oxidizable substrate that nigericin stimulates $\mathrm{Ca}^{2+}$ accumulation in the presence of phosphate. Under no circumstance glutamate supports $\mathrm{Ca}^{2+}$ accumulation in the presence of carboxylic antibiotics, nor does it facilitate $\mathrm{H}^{+}$efflux by $\mathrm{Ca}^{2+}$, after nigericin addition (Panel B, Fig. 7). Figure 8 gives additional evidence for the possible participation of $\mathrm{K}^{+}$ and $\mathrm{H}^{+}$movements on the mechanism of $\mathrm{Ca}^{2+}$ accumulation promoted by carboxylic antibiotics in a medium which contains phosphate. It shows that nigericin catalyzes a $1: 1 \mathrm{~K}^{+} / \mathrm{H}^{+}$exchange in mitochondria suspended in a medium containing $\beta$-hydroxybutyrate plus rotenone without added $\mathrm{Ca}^{2+}$ (Pancl A, Fig. 8). In the absence of an added respiratory inhibitor, and with $\mathcal{R}$-hydroxybutyrate as substrate (Panel B of Fig. 8) the simultancous addition of $\mathrm{Ca}^{2+}$ and nigericin induces $\mathrm{K}^{+}$ release from mitochondria, while $\mathrm{Ca}^{2+}$ completely prevents the passive net $\mathrm{H}^{+}$influx catalyzed by nigericin. Finally, Panel $\mathrm{C}$ of Fig. 8 indicates that $\mathrm{Ca}^{2+}$ does not affect the $\mathrm{H}^{+}$movements catalyzed by nigericin in the presence of $\beta$-hydroxybutyrate plus rotenone.

\section{Discussion}

Carboxylic antibiotics stimulate $\mathrm{Ca}^{2+}$ and phosphate uptake into mitochondria only under conditions of limited $\mathrm{Ca}^{2+}$ loading imposed by phosphate in media supplemented with $\beta$-hydroxybutyrate (Figs. 1.3, Tables I-II). When the latter substrate is replaced for by ATP or else by succinate, glutamate, malate, $\alpha$-ketoglutarate or pyruvate as energy source for transport, the antibiotics block $\mathrm{Ca}^{2+}$ or phosphate accumulation. The inhibition by nigericin-like compounds of the accumulation and oxidation of substrates such as glutamate, pyruvatc, malate or $\alpha$-ketoglutarate, secondary or parallel to an induced-block in the penetration of phosphate $\mid 13,16,23,24,27-29\}$ may account for 
the inability of such substrates to energize $\mathrm{Ca}^{2+}$ accumulation by nigericin. An inhibitory effect by carboxylic antibiotics of the accumulation of A'TP into mitochondria, secondary to the proton movements catalysed by the antibiotics, may also be related to their induced block of both the hydrolysis of ATP stimulated by $\mathrm{Ca}^{2+}$ (cf. ref. [23] Fig. 4A) and the accumulation of $\mathrm{Ca}^{2+}$ supported by ATP hydrolysis (Fig. 4B). On the other hand, it is likely that the ability of $\beta$-hydroxybutyrate but not succinate to support $\mathrm{Ca}^{2+}$ accumulation by nigericin, primarily reflects a coupling existent between the movements of the former substratc, but not succinate, with the translocation of $\mathrm{Ca}^{2+}$ across the membrane. Nigericin does not affect the uptake or the oxidative phosphorylation of saturating concentrations of either substrate $[23,26]$. However, Kimmich and Rasmussen [30] have found that when rat liver mitochondria accumulate $\mathrm{Ca}^{2+}$, only $\beta$-hydroxybutyrate, glutamate, $\mathrm{HCO}_{3}^{-}$and lactate, but not all of the Krebs cycle intermediates, including succinate, served as co-ions for $\mathrm{Ca}^{2+}$ transport. With respect to the above-mentioned penetrant anions for $\mathrm{Ca}^{2+}$ movements, it is worth noting that nigericin inhibits glutamate but not $\beta$-hydroxybutyrate uptake and oxidation. Moreover, in contrast to $\beta$-hydroxybutyrate, neither lactate nor $\mathrm{HCO}_{3}^{=}$could possibly serve as an energy source for ion transport in mitochondria. Thus, $\beta$-hydroxybutyrate emerges as the only possible oxidizable substrate which can fulfil the dual role of being an adequate energy source and an efficient mobile anion for facilitating the transport of $\mathrm{Ca}^{2+}$ stimulated by nigericin.

Previous observations by Rossi et al. [22] showed that, similar to nigericin-like ionophores (Fig. 6), oligomycin also prevents the uncoupling effect of concentrations of phosphate higher than $2 \mathrm{mM}$ on the $\mathrm{Ca}^{2}$ induced respiration. Furthermore, data to be described elsewhere indicate that in the presence of phosphate and $\beta$-hydroxy. butyrate, and similar also to nigericin, oligomycin stimulates $\mathrm{Ca}^{2+}$ accumulation into mitochondria, although to a lesser extent that nigericin. The central question from this analogy is: what is the mechanism responsible for the apparent respiratory control induced in intact mitochondria by nigcricin-like compounds and oligomycin? Mitchell and Moyle [31] suggested that oligomycin caused a decrease in the permability of the mitochondrial membranes to protons. The prevention by oligomycin of the $\mathrm{H}^{+}$influx phase, which discretely follows the proton extrusion linked to substrate oxidation, has been invoked [31] as an important reason for its ability to couple phosphorylating respiration in submitochondrial particles [32]. In fact, it has been shown that oligomycin decreases the proton conductance of membranes from mitochondria [33], chloroplasts $[34,35]$ and chromatophores from photosynthetic bacteria [36]. Data from Figs. 7 
and 8 of the present manuscript indicate not only that $\mathrm{Ca}^{2+}$ prevents the passive net proton accumulation caused by nigcricin in mitochondria (Panel B of Fig. 8), but also that the combination of $\mathrm{Ca}^{2+}$ plus nigericin induces a marked and very slowly reversible proton outflux, higher in magnitude to the rapid cyclic $\mathrm{H}^{+}$release mediated by $\mathrm{Ca}^{2+}$ alone. It is likely that the increase in the availability of protons mediated by nigericin in the interior of the mitochondria, clectrically balanced by the efflux of $\mathrm{K}^{+}$, allows $\mathrm{Ca}^{2+}$ to catalyse a quantitatively more significant $\mathrm{H}^{+}$ efflux phase. In line with this explanation is the ability of $\mathrm{Ca}^{2+}$ to prevent the passive internal acidification caused by nigericin in mitochondria (Fig. 8). The combined efflux of $\mathrm{H}^{+}$and $\mathrm{K}^{+}$mediated by $\mathrm{Ca}^{2+}$ and nigericin (Fig. 7) would also secondarily enhance the extent of the inner negative membrane potential. Thus, by a different mechanism, both nigericin and oligomycin could further stimulate the maintenance of a negative membrane potential in the presence of phosphate, $\mathrm{Ca}^{2+}$ and $\beta$-hydroxybutyratc. This could explain the parallel ability of both antibiotics to couple the phosphorylation of ADP in media containing $\mathrm{Ca}^{2+}$ and phosphate (cf. Rossi et al. [22] and Fig. 6). The above hypothesis could also explain the mechanism by which $\mathrm{Ca}^{2+}$ transport is stimulated in mitochondria by carboxylic antibiotics or oligomycin. By enhancing the extent of an internal negative membrane potential the antibiotics, and particularly nigericin-like compounds, could stimulate an electrophoretic influx of $\mathrm{Ca}^{2+}$ down the electric gradient. In line with this suggestion, it is possible that $\mathrm{Ca}^{2+}$ movements occur in parallel with the translocation of $\mathrm{K}^{+}$and protons catalysed by carboxylic ionophores. However, it is also very attractive to consider the alternative of the antibiotics functioning as $\mathrm{Ca}^{2+}$ mobile carriers across the lipid phase of the mitochondrial membrane.

The accumulation of phosphate which accompanies $\mathrm{Ca}^{2+}$ movements may also be accounted for by the associated internal alkalinization consecutive to the combined effects of $\mathrm{Ca}^{2+}$ and nigericin in proton translocation. The existence of a $\Delta \mathrm{pH}$ across the mitochondrial membrane, parallel to the generated negative membrane potential, would be the reason for the translocation of phosphate as a proton-anion symport $[5,6]$ into the organelle. Evidence which supports this explanation has been given by Palmieri and Quagliariello [37], who, found that in respiratory inhibited mitochondria, the prevention of anion uptake and efflux of endogenous anions were dependent upon the uptake of $\mathrm{H}^{+}$by the mitochondria and vice versa, $\mathrm{H}^{+}$ejection was responsible for stimulation of anion uptake. These findings are essentially the reversc from the suggestions by Harris and Pressman [38] and Van Dam and Tsou [39] who proposed that energization leads to the generation of a positive membrane potential in the mitochondrial interior which, in turn drives anion uptake. 


\section{Reforences}

1. F. D. Vasington and J. V. Murphy, J. Biol. Chem., 237 (1962) 2670.

2. L. Saris, Acta Chem. Scan, 17 (1963) 882.

3. C. S. Rossi and A. L. Lehninger, J. Biol. Chem., 239 (1964a) 3971.

4. B. Chance, J. Biol. Chem., 240 (1965) 2729.

5. P. Mitchell, Chemiosmotic Coupling and Energy Transduction, Glynn Research, Bodmin, Cornwall, 1968.

6. P. Mitchell, Chemiosmotic Coupling in Oxidative and Photosynthetic Phosphorylation, Glynn Research, Bodmin, Cornwall, 1966.

7. G. F. Azzone and A. Azzi, in: Regulation of Metabolic Processes in Mitochondria, Vol. 7, J. M. Tager, S. Papa, E. Quagliariello and E. C. Slater (eds.), Elsevier, Amsterdam, 1966, p. 332.

8. C. S. Rossi, A. Azzi and G. F. Azzone, J. Biol. Chem., 242 (1967) 951.

9. E. Scarpa and G. F. Azzone, European J. Biochem., 12 (1970) 328.

10. D. Johnson and H. A. Lardy, in: Methods in Enzymology, Vol. 10, S. P. Colowick and N. O. Kaplan (eds.), Academic Press, New York, 1967, p. 95.

11. B. C. Pressman, Proc. Natl. Acad. Sci, U.S., 53 (1965) 1076.

12. B. C. Pressman, in: Methods in Enzymology, Vol. 10, S. P. Collowick and N. O. Kaplan (eds.), Academic Press, New York, 1967, p. 714.

13. S. N. Graven, S. Estrada-O. and H. A. Lardy, Proc. Natl. Acad. Sci. U.S., 56 (1966) 654.

14. B. C. Pressman, J. Biol. Chem., 232 (1958) 967.

15. G. Brierley, E. Murer, E. Bachman and D. E. Green, J. Biol. Chem., 238 (1963) 3482.

16. S. Estrada-O. and E. Calderón, Biochemistry (Wash.), 9 (1970) 2092.

17. A. B. Falcone and P. Witonsky, J. Biol. Chem., 239 (1964) 1964.

18. J. B. Martin and D. M. Doty, A nal. Chem., 21 (1947) 946.

19. O. Lindberg and L. Ernster, Methods Biochem. Anal, 3 (1956) 61.

20. H. A. Lardy and H. Wellman, J. Biol. Chem., 201 (1953) 537.

21. J. B. Sumner, Science, 100 (1944) 413.

22. C. S. Rossi, E. Carafoli, Z. Drahota and A. L. Lehninger, in: Regulation of Metabolic Processes in Mitochondria, Vol. 7. J.M. Tager, S. Papa, E. Quagliariello and E. C. Slater (eds.), Elsevier, Amsterdam, 1966, p. 317.

23. H. A. Lardy, D. Johnson and W. McMurray, Arch. Biochem. Biophys., 78 (1958) 587.

24. S. M. F. Ferguson, S. Estrada-O. and H. A. Lardy, J. Biol. Chem. (1971), in press.

25. C. J. Pedersen, Fed. Proc., 27.(1968) 1305.

26. P. F. J. Henderson and J. B. Chapell, Biochem. J., 105 (1967) 16.

27. E. J. Harris, K. Van Dam and B. C. Pressman, Nature, London, 213 (1967) 1126.

28. S. Estrada-O., S. N. Graven and H. A. Lardy, Fed. Proc., 26 (1967) 610.

29. P. J. F. Henderson, J. O. McGivan and B. Chappell, Biochem. J., 111 (1969) 521.

30. G. Kimmich and H. Rasmussen, Fed. Proc., 27 (1968) 1748.

31. P. Mitchell and J. Moyle, Nature, 208 (1965) 1208.

32. C. P. Lee and L. Ernster, in: Regulation of Metabolic Processes in Mitochondria. Vol. 7, J. M. Tager, S. Papa, F. Quagliariello and E. C. Slater (eds.), Elservier, Amsterdam, 1966, p. 218.

33. M. Montal, B. Chance and C. P. Lee, J. Membrane Biol., 2 (1970) 201.

34. S. J. D. Karlish and M. Avron, Biochim. Biophys. Acta, 153 (1968) 153.

35. L. V. Von Stedingk and H. Baltschefsky, Arch. Biochem. Biophys., 117 (1966) 400. 
36. M. Nishimura, K. Kadota and B. Chance, Arch. Biochem. Biophys., 125 (1968) 308.

37. F. Palmieri and E. Quagliariello, European J. Biochem., 8 (1969) 473.

38. E. J. Harris and B. C. Pressman, Biochim. Biophys. Acta, 172 (1969) 66.

39. K. Van Dam and C. S. Tsou, Biochim. Biophys. Acta, 162 (1968) 301. 